\title{
ERRATUM
}

\section{Erratum to: The Economic Burden of Insulin-Related Hypoglycemia in Spain}

Witesh Parekh • Nicki Hoskins · James Baker-Knight •

Antonio Ramirez de Arellano · Pedro Mezquita Raya

Published online: September 1, 2017

(c) The Author(s) 2017. This article is an open access publication

Erratum to: Diabetes Ther (2017) 8:899-913

DOI 10.1007/s13300-017-0285-0

In the original publication, the data and labeling have been incorrectly updated within Fig. 3. The correct data are given here.

The data in Fig. 3, presenting Type 1 Diabetes, Severe; incorrectly reads: $€ 807.92$
This data should read as: $€ 716.82^{\mathrm{a}}$.

The data in Fig. 3, presenting Type 2 Diabetes, Severe; currently reads: $€ 768.72$

This data should read as: $€ 680.49$.

The footnote in Fig. 3 'a The summed total cost is $€ 0.01$ off due to rounding' should be included.

The online version of the original article can be found under doi:10.1007/s13300-017-0285-0.

W. Parekh

European HEOR, Novo Nordisk Ltd., 3 City Place, Beehive Ring Road, Gatwick, UK

N. Hoskins · J. Baker-Knight

DRG Abacus, Bicester, Oxfordshire, UK

A. Ramirez de Arellano ( $\square$ )

EU-HEOR Novo Nordisk, Via de los Poblados, 3 ,

Parque Empresarial Cristalia, Edificio 6-4a Planta,

Madrid, Spain

e-mail: area@novonordisk.com

P. Mezquita Raya

Clínica San Pedro, Hospital Torrecárdenas,

Endocrinology and Nutrition Unit, Almería, Spain 


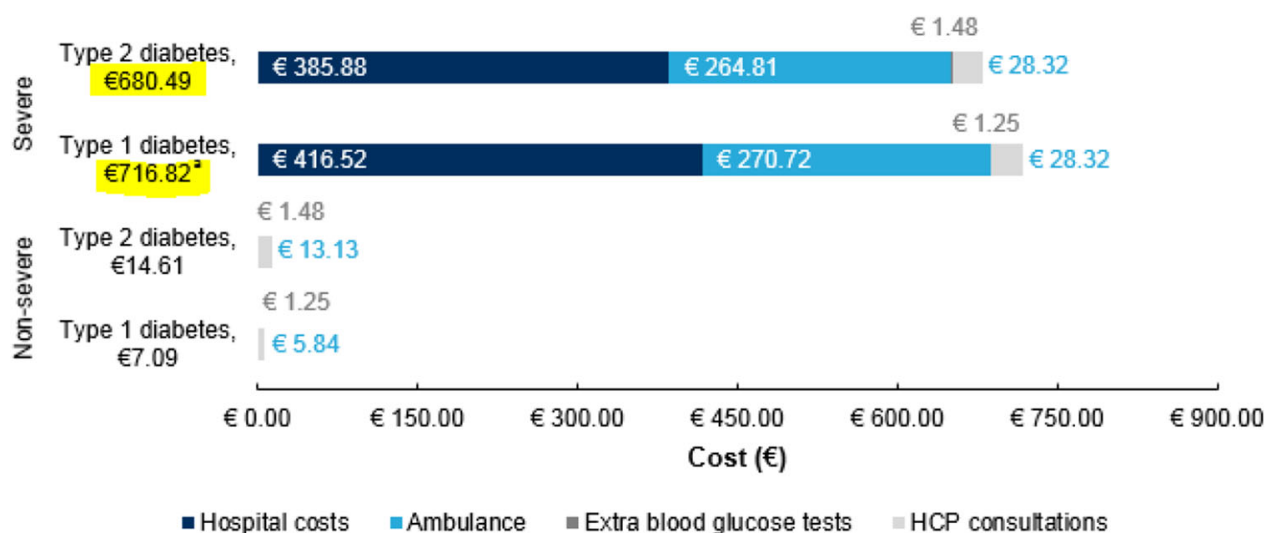

Fig. 3 Cost breakdown for an average hypoglycemic episode. HCP healthcare professional. ${ }^{2}$ The summed total cost is $€ 0.01$ off due to rounding

Open Access. This article is distributed under the terms of the Creative Commons Attribution-NonCommercial 4.0 International License (http://creativecommons.org/licenses/ by-nc/4.0/), which permits any noncommercial use, distribution, and reproduction in any medium, provided you give appropriate credit to the original author(s) and the source, provide a link to the Creative Commons license, and indicate if changes were made. 